MARIA KUCHCIŃSKA

Kujawsko-Pomorska Szkoła Wyższa

Forum Pedagogiczne

2016/2 cz. 1

Bydgoszcz

Wpłynęło: 30.11.2015

Zatwierdzono do druku: 24.05.2016

DOI: $10.21697 / \mathrm{fp} .2016 .2 .12$

\title{
ZASTOSOWANIE METODY ZADANIOWEJ DO ROZWIJANIA KOMPETENCJI DZIAŁANIA MORALNEGO
}

\begin{abstract}
Streszczenie: Wychowawca - jeden z podmiotów procesu wychowania - mógłby racjonalnie wykorzystać wychowawczy potencjał prowadzonych przez siebie zajęć, gdyby poddał refleksji skutki zastosowania przez siebie środków wychowawczych, odpowiadające określonym modelom myślenia pedagogicznego. W przypadku rekomendowanej w tym artykule metody zadaniowej podobny rezultat przy tworzeniu (się) kompetencji moralnego działania mogłaby przynieść analiza możliwości spożytkowania istniejących/intencjonalnie tworzonych zadań kontekstualnych, których rozwiązywanie przez wychowanka jest przekładaniem przez niego wiedzy o dobru na czynienie dobra.
\end{abstract}

Słowa kluczowe: środki wychowania, zadanie rzeczowe, zadanie kontekstualne, kompetencje moralnego działania, metoda zadaniowa.

\section{Wprowadzenie}

Z trzech dróg zdobywania doświadczeń, a mianowicie: przekazu społecznego, obserwacji cudzych zachowań i własnej aktywności, ta trzecia wydatnie sprzyja rozwojowi kompetencji działania - także moralnego - o ile stawia się przed wychowankiem właściwe zadania, a nie quasi-zadania. Zadania rozwijające kompetencje działania moralnego w naturalnych i wyreżyserowanych sytuacjach edukacyjnych stanowią kontekst wszelkiej rzeczowej aktywności wychowanków. I nawet jeśli profesjonalni czy nieprofesjonalni wychowawcy nie zdają sobie sprawy ze znaczenia swojej reakcji/bierności wobec rozwiązywania/wyniku rozwiązania rzeczowego i kontekstualnego zadania przez wychowanka, to rozwiąz(yw)anie drugiego z nich ma swój udział w nabywaniu kompetencji działania moralnego przez wychowanka, bowiem może on stać się podmiotem tego procesu. Tylko stosowanie przez wychowawców metody zadaniowej może sprawić, że wszelka (orientacyjna-decyzyjna-wykonawcza) aktywność wychowanka w sytuacji wychowawczej może i należeć, i zależeć od niego. 
Wskazane w tytule tego artykułu zastosowanie metody zadaniowej do rozwijania kompetencji działania moralnego miało miejsce ponad 30 lat temu podczas budowania przeze mnie teorii metody zadaniowej przy udziale kilku grup seminarzystów. Teoretyczne założenia od początku lat 8o. były weryfikowane w badaniach eksperymentalnych w różnych grupach wiekowych dzieci i w ramach kilku form zajęć (lekcyjnych, świetlicowych, kółek zainteresowań, drużyn harcerskich). Cele finalne były wówczas wyrażane w języku postaw (współodczuwania, opiekuńczości, poszanowania własności, kolektywizmu i patriotyzmu). Wyniki zostały opublikowane w artykułach naukowych z lat 8o. i autorskich monografiach z lat 1988-1997. W przygotowaniu jest książka ukazująca możliwości zastosowania metody zadaniowej do indywidualizowania oddziaływań drogą stopniowania trudności.

Ten artykuł ma pokazać możliwość refleksyjnego podejścia do praktyki oglądanej w krzywym zwierciadle teorii (posługuję się tu sformułowaniem zapożyczonym od Elżbiety Paszkiewicz [1983]). Praktyka jest to o tyle specyficzna, że występują w niej dwa działające podmioty powiązane relacją współdziałania (Pszczołowski 1978, s. 228) i każdy z nich może posługiwać się zarówno zadaniem, jak i pozostałymi środkami (samo)wychowania. Wychodząc zatem od podmiotów wychowania, przez zasygnalizowanie następstw podporządkowania praktyki wychowawcy (jednego $\mathrm{z}$ tych podmiotów) różnym modelom myślenia pedagogicznego, idąc dalej, spróbuję pokazać, co traci główny podmiot wychowania (wychowanek), gdy mający z nim współpracować nad rozwojem wspólnik nie poddaje autorefleksji swej praktyki stosowania zadań w wychowaniu. Tworzenie wychowankom szans czynienia dobra tu i teraz omawiam jako następstwo refleksyjnego posługiwania się zadaniem kontekstualnym (istniejącym w tle każdego zadania rzeczowego) jako środkiem kształtowania się - w procesie wychowania - kompetencji zachowań moralnych.

\section{Podmioty wychowania}

Osobowość wychowanka kształtuje się w jego własnym działaniu. To wychowanek bowiem (czasem za sprawą lub przyzwoleniem wychowawcy, często pod jego nadzorem) krocząc trzema drogami wzbogacania doświadczeń (Łukaszewski 1984), jest głównym sprawcą swego rozwoju. Może zatem działać, poddając się przekazowi społecznemu, może pozwolić uwieść się modelowi lub może wejść w rolę interpretatora, a nawet twórcy zdarzeń/znaczeń, podejmując aktywność zadaniową.

Po stronie wychowawcy (oprócz wymienionych: słowa, modelu i zadania) mamy jeszcze czwarty środek wychowania - sankcje za określony poziom/wynik aktywności lub za bierność wychowanka, czyli kary i nagrody (Konarzewski 1982) - których wychowawca może użyć do kierowania, sterowania, urabiania i stymulowania/ wspomagania działań wychowanka (Gnitecki 1994). Czynności te wpisują się w dwie - podającą i poszukującą (Banasiak 1996) - strategie oddziaływania wychowawcy na główny podmiot rozwoju, tj. na wychowanka. I chociaż osobowość 
wychowanka rozwija się w działaniu wychowanka (nieograniczonym do słuchania i naśladowania), to w placówkach marginalizujących swą funkcję emancypacyjną uczniowie, niestety, mają „iluzję działania poprzez działania nauczyciela” (Paulo Freire, cyt. za: Blusz 1992, s. 97).

\section{Następstwa oddziaływania różnymi środkami wychowania wedle różnych modeli myślenia pedagogicznego}

Warta uwagi jest specyfika stosowania poszczególnych środków, gdy praktyka wychowawcy jest podporządkowana odmiennym strategiom wywoływania/wspierania rozwojowych zmian lub kierowania nimi z zewnątrz, a wychowanek może wzbogacać swe doświadczenia trzema drogami.

Tabela 1. Ingerencja wychowawcy w rozwój wychowanka wedle strategii podającej

\begin{tabular}{|c|c|c|c|}
\hline $\begin{array}{c}\text { Ingerencja } \\
\text { wychowawcy }\end{array}$ & $\begin{array}{l}\text { „Powiem Ci, } \\
\text { a będziesz } \\
\text { wiedział” }\end{array}$ & $\begin{array}{l}\text { „Ćwicz wskazane } \\
\text { czynności, } \\
\text { a nauczysz się" }\end{array}$ & $\begin{array}{l}\text { „Pokażę Ci, } \\
\text { a dowiesz się" }\end{array}$ \\
\hline $\begin{array}{c}\text { Środek } \\
\text { wychowania }\end{array}$ & słowo & zadanie & model \\
\hline $\begin{array}{l}\text { Przykład zlecanej } \\
\text { wychowankowi } \\
\text { aktywności }\end{array}$ & $\begin{array}{l}\text { „Posłuchaj/ } \\
\text { przeczytaj, co } \\
\text { jedzą różne } \\
\text { ptaki, a będziesz } \\
\text { wiedział, czym } \\
\text { karmić te, które } \\
\text { tu przylatują” }\end{array}$ & $\begin{array}{l}\text { „Napełniaj kar- } \\
\text { mnik ziarnami } \\
\text { XYZ, owocami } \\
\text { abc, tłuszczem } \\
\text { x, zmieszaj } \\
\text { wszystko. Wystaw } \\
\text { karmę tym } \\
\text { ptakom” }\end{array}$ & $\begin{array}{l}\text { „Naśladuj moje/ } \\
\text { jego czynności } \\
\text { przy napełnianiu } \\
\text { ptasiej stołówki, } \\
\text { a nauczysz się } \\
\text { karmić te ptaki” }\end{array}$ \\
\hline Rola wychowanka & $\begin{array}{l}\text { Odbiorca } \\
\text { zdarzeń/znaczeń }\end{array}$ & $\begin{array}{l}\text { Odtwórca } \\
\text { algorytmów }\end{array}$ & $\begin{array}{l}\text { Odtwórca } \\
\text { zdarzeń/znaczeń }\end{array}$ \\
\hline $\begin{array}{l}\text { Droga wzbogaca- } \\
\text { nia doświadczeń }\end{array}$ & Przekaz społeczny & & $\begin{array}{l}\text { Obserwacja } \\
\text { cudzych } \\
\text { doświadczeń }\end{array}$ \\
\hline
\end{tabular}

Źródło: opracowanie własne.

W ramach przekazu społecznego wychowawca stosuje też czwarty środek wychowania - sankcje nagradzające i karzące. Wobec tego środka wychowanek pełni rolę biorcy zdarzeń następujących po jego zachowaniu w określonej sytuacji (a emitowanych przez wychowawcę będącego w tych okolicznościach wyrazicielem 
społecznej aprobaty bądź dezaprobaty dla zadaniowej aktywności/bierności wychowanka w określonej sytuacji).

Rola podjęta przez wychowanka wyznacza zakres jego podmiotowości.

Tabela 2. Strategia poszukująca - wspomaganie przez wychowawcę dążności rozwoju wychowanka

\begin{tabular}{|c|l|l|}
\hline Ingerencja wychowawcy & „Przeżyj, a dowiesz się” & „Zrób sam, a nauczysz się” \\
\hline Środek wychowania & zadanie & zadanie \\
\hline $\begin{array}{c}\text { Przykład zalecanej wy- } \\
\text { chowankowi aktywności }\end{array}$ & $\begin{array}{l}\text { „Przyjrzyj się zachowa- } \\
\text { niom ptaków ucztują- } \\
\text { cych w napełnionym } \\
\text { karmniku i wnioskuj } \\
\text { o ich upodobaniach } \\
\text { smakowych” }\end{array}$ & $\begin{array}{l}\text { „Napełniaj ptasią stołówkę } \\
\text { ko kolei rozmaitym po- } \\
\text { katunki i obserwuj, jakie } \\
\text { gatołowników jaki } \\
\text { pokarm zjadają” }\end{array}$ \\
\hline Rola wychowanka & $\begin{array}{l}\text { Interpretator } \\
\text { zdarzeń/znaczeń }\end{array}$ & $\begin{array}{l}\text { Twórca } \\
\text { zdarzeń/znaczeń }\end{array}$ \\
\hline $\begin{array}{c}\text { Droga wzbogacania } \\
\text { doświadczeń }\end{array}$ & Własna aktywność wychowanka \\
\hline
\end{tabular}

Źródło: opracowanie własne.

\section{Zadanie rzeczowe i kontekstualne jako środki sytuacji wychowawczej}

Człowiek staje przed zadaniem ${ }^{1}$, gdy w którymkolwiek ze składników jego aktualnej sytuacji zaistnieje, możliwa do usunięcia, rozbieżność ujemna, tj. gdy dzieje się „coś nie tak” z którymś składnikiem jego sytuacji (w porównaniu ze standardem normalnego/idealnego stanu dla tegoż składnika). Owo „coś nie tak” może więc dotyczyć zewnętrznych i/lub wewnętrznych warunków aktywności lub bierności człowieka, samej aktywności/bierności lub jej celu (tj. każdego z trzech składników każdej sytuacji).

Istotą zadania jest bezpośredni kontakt jednostki z otoczeniem (społecznym, kulturowym, przyrodniczym) w trakcie usuwania rozbieżności ujemnej (w ramach dążenia do utrzymania homeostazy poznawczej), w trakcie którego jednostka gromadzi wiedzę:

1 Bez udziału bądź za sprawą kogoś innego. Świadome posługiwanie się przez wychowawcę istniejącą rozbieżnością ujemną lub jej preparowanie w zewnętrznych warunkach wychowanka w celu wywołania (usuwającej rozbieżność ujemną) aktywności tego wychowanka nazywam metodą zadaniową, jest to bowiem rozmyślny sposób uruchomiania własnej aktywności wychowanka, stwarzanie mu szansy wzbogacania doświadczeń tą drogą (Kuchcińska 1997, s. 8). 
a) konceptualną - „o czymś” (o sobie, otoczeniu, własnych i cudzych relacjach $\mathrm{z}$ otoczeniem);

b) proceduralną - „o tym, w jaki sposób coś wykonać” (o metodach dochodzenia do celu, programach regulowania stosunków pomiędzy sobą a otoczeniem, np. społeczno-przyrodniczym).

Przedmiotem aktywności wychowanka są zwykle surowce - tworzywa, które mają ulec przekształceniu w określony (często nawet przez wychowawcę w zadaniu dydaktycznym opisany) materialny wytwór, np. rzeźba z gliny czy preparat mikroskopowy. Wytwór ten jest przez wychowanka zazwyczaj traktowany jako cel jego działalności w danym ugrupowaniu (kółko plastyczne) albo jako cel jego aktywności w trakcie określonych zajęć (lekcja plastyki, biologii). Z tej racji poręcznie jest nazwać je za Dejnarowicz (1977) zadaniami rzeczowymi.

Objęcie wychowawczą ingerencją (obserwacją oraz - tylko „w razie” i „na miarę” potrzeby - interwencją) sposobu rozwiązywania nie tyle zadań rzeczowych, ile (własnych, pozornie własnych i częściowo zleconych) zadań kontekstualnych nie odbiera wychowankom podmiotowości (choć - jak każda ingerencja wychowawcza - ogranicza ją, stanowiąc opresję). W przypadku sterowania i urabiania aktywności wychowanka, podejmującego i/lub rozwiązującego zadania, jego swoboda jest mniejsza niż w przypadku kierowania i stymulowania/wspomagania jego aktywności (z racji możności stanowienia celu przez wychowanka lub z jego udziałem).

Rozwiązując zadanie dydaktyczne/rzeczowe, uczeń wykonuje pewne czynności, przeżywa, a czasami działa na materialnym tworzywie, np. wertuje książkę, zapisuje coś w czymś, czymś coś podkreśla, skleja lub kroi coś, coś z czegoś przelewa lub do czegoś przekłada, coś wałkuje lub zgniata, jedno składa, inne rozbiera itp. Następstwem aktywności, a zwłaszcza uczniowskich działań (czynności o przedmiotowym charakterze) po rozwiązaniu dydaktycznego/rzeczowego zadania są więc zmiany zewnętrznych warunków, które zwykło się przyjmować jako pierwotne wobec zmian wewnętrznych warunków wychowanka.

Przedmiotem działań wychowanka są jednak też fragmenty rzeczywistości „uwikłane” w powstawanie wytworu, ale niebędące ani surowcem, ani narzędziem jego obróbki. Przykładowo, w przekształcanie gliny w rzeźbę uwikłane są „mój ubiór” i „ich dostęp do surowca oraz narzędzi” oraz „nasz stół”, „twój pomysł”, a także „jej bezpieczeństwo”. Rozwiązując rzeczowe zadanie (np. formując rzeźbę), wychowanek równocześnie stoi wobec zadań związanych z przykładowo wymienionymi obiektami. Okazując bierność lub wybierając określone zachowanie wobec np. ubioru, dostępu, pomysłu, bezpieczeństwa itd., wychowanek okazuje swój stosunek do nich. Z każdym z nich w każdej chwili może stać się „coś nie tak”, a z pewnością w stosunku do każdego $\mathrm{z}$ nich można zabiegać o utrzymanie stanu istniejącego z czasu poprzedzającego realizację zadania rzeczowego, np. rzeźbienie (Kuchcińska 1988; 1996).

Wydaje się, że trudno znaleźć lepsze określenie niż wychowawcze dla nazwania tych zadań, które powstają na kanwie zadań rzeczowych, ale ponieważ nie jest to 
jednak rozwiązanie pozbawione ułomności (może bowiem - wbrew intencjom piszącej - sugerować brak wychowawczego aspektu w zadaniach rzeczowych) nazywam je zadaniami kontekstualnymi (Kuchcińska 1997).

\section{(Anty)przykłady kształtowania (się) kompetencji działania moralnego podczas rozwiązywania zadań rzeczowych/dydaktycznych na lekcjach}

Zachowanie moralne w konkretnej sytuacji kształtuje, ale i ujawnia kompetencje wychowanka. Przywołam fakty: w trakcie krojenia liści (w celu przygotowania preparatu do obserwacji pod mikroskopem) przez jakiegoś ucznia zostało wyrażone, a przez innego wyszydzone przekonanie o tym, że świat roślin nie tylko doznaje np. cierpienia, lecz także komunikuje je sobie wzajemnie.

Rzeczowe zadania uczniów dotyczyły w pierwszym rzędzie przygotowania owego preparatu, a w dalszej kolejności poczynienia określonych obserwacji, pozwalających np. na poznanie komórkowej budowy liścia. W kontekście pierwszego z tych zadań (przygotowania preparatu) w zewnętrznych warunkach (w społecznym otoczeniu) zaszły zdarzenia, które postawiły uczniów - świadków zdarzeń w pozadydaktycznej sytuacji zadaniowej. Bez zadań dydaktycznych/rzeczowych być może wcale nie doszłoby do opisanego tu ujawnienia określonych przekonań przez jednego ucznia i godnego dezaprobaty wyszydzenia tych przekonań przez drugiego. Oba te zdarzenia zaistniały w kontekście wykonywania zadania rzeczowego, chociaż nie należały ani do zadania sporządzenia preparatu, ani do zadania poznania komórkowej budowy liścia. W tym sensie mówić można o sytuacyjnej genezie kontekstualnego zadania.

Dezaprobujące zareagowanie na szyderczy komentarz - będące treścią zadania kontekstualnego - stawia wychowanków przed kolejnym zadaniem kontekstualnym zawartym w pytaniu o sposób wyrażenia dezaprobaty dla szydzenia z cudzych poglądów. Teoretycznie jest możliwa fizyczna i/lub werbalna agresja, ale powiedzmy, że wychowanek wyrósł już z tak prymitywnych reakcji na zło, podobnie jak wyrósł z chodzenia na skargę w obronie wyszydzanego. Odrzuca więc (na podstawie kryterium etycznego) te programy zareagowania na zło. Czy są inne? Szydercę można ukarać. Karzące nie tylko symbolicznie może być odsunięcie się od niego lub np. rewanż. Jeśli jednak z szydercą nie łączy mnie - może rozważać wychowanek - żadna więź emocjonalna, a nie uda mi się uzyskać współdziałania ze strony znaczących dla niego osób, to moje odsunięcie się (od niego) nie spełni karzącej roli. Nie może to więc być ten program, jeśli do jego wyboru zastosuje się kryterium pragmatyczne. A czy może nim być rewanż, w myśl starotestamentowej zasady „oko za oko, ząb za ząb”? O ile w ogóle uznać go za dopuszczalny, to w tych okolicznościach nie powinien mieć zastosowania. Tu bowiem zupełnie nie chodzi o „odczuj to na własnej skórze”. Nie w tym rzecz, co poczuje wyszydzony szyderca (który nadto skłaniany byłby w takich okolicznościach do skoncentrowania się na sobie). Tu ważne jest, do czego ma prawo ofiara szydercy, co się z tym prawem stało, 
gdy szydził i co w związku z tym czuje/ma prawo czuć ofiara. Wniosek: program wedle reguły „oko za oko” - jako niecelowy - nie jest wart uwzględnienia. Zatem może właśnie skierowanie rozmowy na prawo człowieka do odmienności i losy tego prawa w stosunkach międzyludzkich pozwoli wygasić ów szyderczy śmiech? Być może w trakcie takiej debaty powstanie lustro, w którym szyderca będzie mógł się przejrzeć (i może mu się nawet wydawać, że dopóki inni rozprawiają, on przegląda się w tym lustrze w samotności).

Ta wyimaginowana droga myślowa wychowanka, który poczułby się w sytuacji zadaniowej, zetknąwszy się ze złem w relacji międzyludzkiej, ukazuje sytuacyjną genezę zachowań moralnych, przynajmniej w zakresie pierwszej decyzji o zareagowaniu na zło i w zakresie drugiej decyzji o wyborze sposobu i/lub formy zareagowania na zło. Podejmowanie każdej z decyzji jest zachowaniem moralnym (i moje doświadczenie w kontaktach z dziećmi pozwala stwierdzić, że to zachowanie jest już poznawczo dostępne uczniom klas 3-4 szkoły podstawowej).

Aczkolwiek wyimaginowana droga myślowa wychowanka stanowi wizję jego przygotowywania się do samodzielnego działania w życiu dorosłym (co zakłada jako cel wynikowy - model kompetencji moralnej), jest też symulacją jego samodzielnego moralnego działania tu i teraz, już w dzieciństwie. Stanowi bowiem wizję pozyskiwania/rozwijania/utrwalania władzy moralnego sądzenia w naturalnych sytuacjach wychowawczych. Jest projekcją podejmowania przez ucznia osobistych wyborów i planowania ich realizacji, jego refleksji nad czynami innych ludzi i własnymi zamiarami. Refleksja taka jest możliwa po opanowaniu podstawowych wiadomości moralnych. Takie wiadomości (zależnie od moralnego poziomu otoczenia, w którym dziecko wzrasta) bywają dostępne we wczesnej fazie rozwoju ${ }^{2}$.

Wśród licznych zadań wykonywanych przez ucznia na lekcji zwłaszcza kontekstualne należą do tych o najwyższym potencjale osobotwórczym, ponieważ uczeń sam sobie je stawia (są to zatem zadania własne, najczęściej poza- lub ponadosobiste [Łukaszewski 1984]). Natomiast dydaktyczne/rzeczowe zadania częściej są przed uczniem stawiane przez nauczyciela odpowiednio aranżującego sytuację,

2 Ostatnio dwu i półlatek, zanosząc się płaczem, przyszedł do mnie z wiadomością: „Ja ją udeziłem!”. Co uderzył? Interaktywną zabawkę - worek ze zwisającym z niego ogonem - wydającą po klaśnięciu/klepnięciu różne dźwięki: nie tylko kocie miauczenie, ale i o brzmieniu przypominającym ludzką mowę. Obserwowałam jego zabawę i byłam zdania, że ostatnie pobudzenie zabawki do wydania dźwięku (zadanie rzeczowe) było agresywne. Zanim się jednak namyśliłam, czy i jak zareagować, dziecko - poruszone własnym zachowaniem - samo przyszło z płaczem (odczytanym przeze mnie jako skrucha - zadanie kontekstualne) po wychowawczą ingerencję. W takich okolicznościach pocieszenie typu: „Ale nic się nie stało. To przecież tylko zabawka. Nikt nie ucierpiał", byłoby wychowawczym nieporozumieniem. Owszem, stało się źle, ale można tego więcej nie powtórzyć. Wtedy to zło nie powiększy się. Łzy równie szybko, jak się pojawiły, zniknęły. Nie mam pewności, bo na tego typu wywiad z malcem za wcześnie, ale przypuszczam, iż uspokoiła go informacja, że samemu można powstrzymać czynienie zła. Gdyby tak w istocie było, to podjęte przeze mnie urabianie wychowawcze okazałoby się skuteczne. 
a więc świadomego położenia, w jakim znajduje się uczeń na lekcji ze względów dydaktycznych. W obu przypadkach zadania ucznia są pochodne od sytuacji, jaką jest lekcja. Rzecz w tym jednak, że współsprawca rozwoju ucznia - nauczyciel najczęściej jest świadomy tylko dydaktycznej sytuacji i nawet nie obdarza uwagą tego położenia, w którym - ze względu na kontekst rozwiązywania zadań dydaktycznych - stawia ucznia aranżowana przez nauczyciela sytuacja dydaktyczna. W ten sposób powszechnie marnowany jest potencjał wychowawczy lekcji.

$\mathrm{W}$ prowadzonym ponad 30 lat temu pod moim kierunkiem badaniu na 63 lekcjach pracy techniki odnotowano 183 sytuacje, w których uczniowie podjęli zadania kontekstualne, regulując stosunki z różnymi fragmentami rzeczywistości uwikłanej w rozwiązywanie przez nich zadań rzeczowych. Profesjonalni wychowawcy wykazali kompletny brak reakcji w 32,8 proc. tych sytuacji, w 2,2 proc. własnymi działaniami usunęli zadania kontekstualne z sytuacji uczniowskiej, a w 33,3 proc. ich interwencją wychowawczą uczniowie zostali pozbawieni podmiotowości. Zatem 68,3 proc. podjętych przez uczniów zadań kontekstualnych nie zostało włączonych do procesu wychowania za sprawą nauczycieli (Kuchcińska 1996, s. 28-29).

Kolejny przykład „antykierowania” z zewnątrz rozwojem kompetencji działania moralnego pochodzi z tych samych badań. Na lekcji pracy techniki zadanie dydaktyczne (rzeczowe) stanowiło warunki zmiany dwu umiejętności ucznia, po pierwsze, technologii obróbki drewna, a po drugie, urzeczywistniania projektu wykonanego w określonej skali. Obróbka drewna miała na tej lekcji objąć cięcie po linii prostej i po łuku, wygładzanie krawędzi oraz nawiercanie otworu. Absolutnie nic (poza czynnikami zależnymi od nauczycielki) nie uzasadniało potrzeby wykonania w tych celach tylko jednego dla całej klasy projektu (narzucającego wszystkim uczniom jednolity kształt i wymiary wytworu). W trakcie wykonywania przez uczniów opisanego zadania dydaktycznego pojawiła się nieoczekiwanie kontekstualna sytuacja zadaniowa. Otóż ujednolicenie projektu wytworu sprawiło, że uczennicy A została spora nadwyżka surowca (deski). Uczennicy B natomiast przecinana sklejka rozpadła się na pojedyncze arkusze. Uczennica A natychmiast poczuła się w sytuacji zadaniowej, wobec czego zaoferowała koleżance posiadaną przez siebie nadwyżkę surowca. Pech jednak chciał, że gabaryty tej nadwyżki były mniejsze od narzuconego dzieciom projektu, a także kierująca pracą nauczycielka była wyposażona w takie wewnętrzne warunki, które nie pozwoliły jej zaakceptować rozwiązania sytuacji według projektu dzieci. Skoro wytwór uczennicy B, w przypadku skorzystania z koleżeńskiej pomocy, nie będzie odpowiadał projektowi założonemu na początku lekcji, to ta uczennica nie może $\mathrm{z}$ oferowanego surowca skorzystać - stwierdziła nauczycielka. Jak widać, nie rozumiała, że lepiej zmienić w tym przypadku projekt (obligatoryjnie narzucony uczniom przez tę nauczycielkę), niż być pozbawionym możliwości uczenia się: 1) obróbki drewna; 2) wdzięcznego przyjęcia daru; 3) sztuki dziękowania za doświadczaną pomoc; 4) dzielenia się z bliźnim nadwyżką własnych zasobów i 5) uczenia innych uczniów tej klasy - przez modelowanie - opiekuńczości wobec bliźniego w potrzebie. 
Z woli nauczycielki uczennica B do końca (dwu łączonych) lekcji pozostała bezczynna. I ona, i jej rówieśnicy z klasy mieli okazję doświadczyć niemożności pokonania barier wynikających z określonych wewnętrznych warunków osoby posiadającej, niestety, władzę, która przyczyniła się do antywychowawczego absurdu. Ta nauczycielka z wyższym wykształceniem, ucząca w mieście wojewódzkim zapewne byłaby oburzona, słysząc, że nie tylko zaprzepaściła naturalną sytuację wychowawczą, tym samym nie wsparła rozwoju kompetencji działania moralnego swych uczniów, ale poziomem analizy sytuacji nie dorównała uczennicy 4 klasy szkoły podstawowej.

\section{Stwarzanie wychowankom szans czynienia dobra „tu i teraz”}

W edukacji za pośrednictwem zadań (z racji regulacyjnej i regulowanej funkcji spełnianych przez zadanie) - przy kumulacji zadań rzeczowych z kontekstualnymi - zamierzonym wynikiem jest nie tylko uczenie się przez wychowanka skutecznego, ale też moralnie (indywidualnie i społecznie) akceptowanego układania się ze światem. Wybór kryteriów moralnych nie jest tutaj uznany za całkowicie prywatną sprawę wykonawcy zadania ani nawet zleceniodawcy, z racji upolitycznienia edukacji w każdym ustroju, na co zwracał uwagę już Platon (Kuchcińska 1996).

Kierowanie z zewnątrz treścią styczności społecznych dziecka jest również wskazane, jeśli nauczyciel-wychowawca chce wspierać je w stosowaniu zasad tolerancji w regulowaniu stosunków z otoczeniem społecznym. Respektowania prawa innych do odmienności można się uczyć, mając kontakt z osobami z różnych kręgów kulturowych, o różnych sprawnościach czy ułomnościach. Wykorzystanie lub tworzenie możliwości nawiązywania takich kontaktów społecznych stanowi sposób na przekształcanie elementów sytuacji w bodźce, tj. inspirowania aktywności zadaniowej dziecka.

Przy wspieraniu dziecka w uczeniu się umiejętności współodczuwania $\mathrm{z}$ innymi nie wystarcza samo wykorzystanie lub stworzenie możliwości nawiązania bezpośrednich kontaktów z doznającym otoczeniem. Tu niezbędne jest także wykorzystanie faktu lub sprawienie, że doznająca istota (człowiek, zwierzę) czyni z dziecka adresata potrzeby uzyskania oddźwięku dla własnych doznań. Nawet pies, nie mówiąc już o człowieku, nie z każdym chce dzielić się swoją radość i nie u każdego szuka pocieszenia/pomocy w cierpieniu. Do kompetencji człowieka należy umiejętność trafnej oceny, czy ktoś jest tym właściwym adresatem (aby nie narzucać się, ale i nie mrozić kogoś dystansowaniem się od jego doznań).

Bezpośrednia styczność $\mathrm{z}$ określonym fragmentem rzeczywistości jest także nieodzowna wtedy, gdy wynikiem dziecięcej aktywności ma być jakaś forma wyrażenia szacunku wobec określonych obiektów. Obowiązuje to zarówno, gdy w grę wchodzi poszanowanie cudzych pomysłów czy dobrego imienia, jak i poszanowanie ludzkiego trudu lub wytworów pracy. Dotyczy to także szacunku dla zdrowia i wszelkich przejawów życia. Uczenie się tego szacunku nie może przebiegać 
w okolicznościach eliminujących, np. zagrożenia zdrowia, typu: jazda rowerem, pływanie, posługiwanie się ostrymi narzędziami, przebywanie z dala od urządzeń elektrycznych itp. Toteż wykorzystywać i tworzyć okazję do bezpośredniego kontaktu, stawiającego dziecko "oko w oko" z obiektem lub jego zagrożeniami, stanowi sposób na to, aby inicjować aktywność zadaniową takiej treści.

Potocznie termin „kompetencje” jest stosowany dla określenia należytego wykonania danej czynności przez konkretny podmiot, i to ze względu na wynik tej czynności szacujemy, czy sprawca był kompetentny (Furmanek 1997). Wedle Słownika języka polskiego (2005) „kompetencje” to zakres czyjejś wiedzy, odpowiedzialności i umiejętności. „Kompetencja społeczna” zaś bywa definiowana jako „udowodniona (w pracy, nauce oraz w rozwoju osobistym) zdolność samodzielnego stosowania posiadanych umiejętności z uwzględnieniem zinternalizowanego systemu wartości” (https://pl.wikipedia.org/wiki/). Ta ostatnia definicja zbliża nas najbardziej do pojmowania kompetencji moralno-etycznych. Zdaniem Roberta Kwaśnicy (2004) jest to zdolność prowadzenia refleksji moralnej, a nie tylko wiedza o normach i nakazach moralnych; te kompetencje są zawarte w pytaniach o prawomocność moralną naszego postępowania.

Według modelu Dietricha Bennera składnikami kompetencji etyczno-moralnej są:

a) podstawowa wiedza etyczna;

b) kompetencja sądzenia moralnego;

c) kompetencja moralnego działania.

Tak ujęte kompetencje moralne nie przekładają się automatycznie na moralne postępowanie, trzeci bowiem element kompetencji w tym modelu sprowadza moralne działanie do władzy sądzenia oraz "do indywidualnego i publicznego rozważania kwestii moralnych, a także samodzielnego podejmowania decyzji” (Benner i in. 2010, s. 11).

Ważne jest, aby dojrzewający człowiek uczył się patrzeć na świat z wielu perspektyw i poszukiwał odpowiedzi na pytanie, na czym polega dobro. Nie można jednak przyjmować a priori założenia, że namysł „nad moralną prawomocnością naszych zachowań" (Horowski 2012, s. 199) będzie prowadził do moralnych zachowań, ponieważ kompetencje moralne nie przekładają się automatycznie na moralne postępowanie.

W poznawczej teorii rozwoju (leżącej u podstaw metody zadaniowej w edukacji) rozwój moralności łączony jest z aktywną zmianą we wzorach myślenia, wywołaną przez doświadczane sytuacje rozwiązywania problemów (Kohlberg, Mayer 1993), tj. rozwiązywania niestereotypowych zadań (zwłaszcza kontekstualnych). Także „W tradycji arystotelesowsko-tomistycznej wychowanie moralne związane jest nie tyle z nauczaniem, przekazywaniem norm, ale umożliwieniem doświadczenia dobra, które będzie pociągało - doświadczenie da wychowankowi pewność, że realizacja tego konkretnego dobra przyniesie mu szczęście" (Horowski 2012, s. 206) 
Te myśli są też obecne w przywołanym modelu kompetencji moralnej, „w którym główny nacisk pada na przekaz podstawowych wiadomości moralnych, rozwijanie władzy sądzenia i działania moralnego" (Benner i in. 2010, s. 212). To ostatnie oznacza jednak „wspieranie [...] refleksji nad czynami własnymi i innych ludzi, podejmowanie osobistych wyborów i projektowanie ich realizacji” (Benner i in. 2010, s. 9; podkr. M.K.). Wchodzą tu zatem w grę czynności orientacyjne i decyzyjne. Zastosowanie metody zadaniowej w kształtowaniu (się) działania moralnego sprawia, że to działanie pojmowane jest dosłownie (przyjmując rozróżnienie tych pojęć za T. Tomaszewskim [1971] i M. Tyszkową [1977]) jako działanie o przedmiotowym charakterze, a nie tylko czynności (poznawcze). Zastosowanie metody zadaniowej zatem sprawia, że dobro może być czynione, że opracowane (w trakcie wykonywania czynności poznawczych) projekty realizacji mogą być wcielane w życie (a następnie ponownie poddane refleksji zarówno w ramach uczenia się, jak i nauczania).

Natomiast szkolne nauczanie filozofii, etyki, wyposaża uczniów w nieodzowne wiadomości, tworząc tym samym szanse do rozwijania władzy sądzenia. Daje też możliwość działania moralnego w postaci rozwiązywania quasi-zadań w sytuacjach istniejących „na niby”, powstałych w wyobraźni, rozważanych teoretycznie. Prowadzone przeze mnie badania ujawniły, że takie quasi-zadania wydatnie przyczyniają się do wyposażania wychowanków w wiedzę i jej zdecydowanie lepsze rozumienie przez nich, ale - niestety - w nikłym stopniu zmieniają ich zachowania $\mathrm{w}$ naturalnych sytuacjach zadaniowych ${ }^{3}$. Nadają się zatem do wzbogacania wiadomości moralnych oraz do rozwijania władzy sądzenia, czyli rozważania kwestii moralnych. Mogą służyć też do podnoszenia na wyższy poziom umiejętności zajmowania w problemach moralnych własnego stanowiska (co wymaga odwagi cywilnej i ją kształtuje) oraz przy projektowaniu przez wychowanka realizacji osobistych wyborów moralnych. Nie są natomiast przydatne przy przechodzeniu ze sfery fikcji do sfery rzeczywistości w realizacji projektów moralnego zachowania. Temu służą naturalne lub przez wychowawców reżyserowane sytuacje wychowawcze, zawierające autentyczne zadania kontekstualne, przy rozwiązywaniu których zarówno ujawniają, jak i kształtują się kompetencje moralne.

\section{Zakończenie}

W kontekście projektu $\mathrm{ETiK}^{4}$ moją uwagę zwraca passus przywoływanego powyżej już tekstu: „do zadań lekcji etyki w szkole nie należy wpajanie uczniom przekonania o jedynej słuszności pewnego systemu wartości ani określonego

3 Te ustalenia korespondują też z poglądami wyrażonymi w pracy S.B Simon i in. (1992).

4 Skrót ETiK powstał od niemieckiej nazwy projektu - „Entwicklung eines Testinstrumentes zu einer didaktisch und bildungstheoretisch ausgewiesenen Erfassung moralischer Kompetenzen, bezogen auf den Ethik-Unterricht an offentlichen Schulen”, co w języku polskim oznacza „Rozwój 
rozumienia cnoty. [...] głównym celem szkolnego nauczania etyki ukierunkowanego na kształtowanie kompetencji jest wspieranie w uczących się rozwoju umiejętności sądzenia moralnego przez konfrontowanie ich $\mathbf{z}$ wielością form myślenia etycznego i kształtowanie dzięki temu postawy dialogu, sprzyjającej poszukiwaniu kompromisowych rozwiązań dla problemów moralnych zarówno własnych, jak i cudzych oraz ogólnospołecznych (publicznych)" (Benner i in. 2010, s. 11; podkr. - M.K.).

Odrzucając istnienie wartości absolutnych, projekt ten zakłada zatem relatywizm moralny, i tym samym (wypracowany w dialogu) kompromis uznaje za standard stanu normalnego. Stawia to nauczycieli etyki, będących zwolennikami oddziaływań edukacyjnych, wedle myślenia kategoriami pedagogiki technologicznej (preferujących sterowanie i urabianie), przed dylematem moralnym przy wykonywaniu zawodu, natomiast w pełni satysfakcjonuje zwolenników kierowania i wspierania (Gnitecki 1996) wychowanka, czyli liberałów wychowawczych zainteresowanych powstawaniem kompetencji.

Edukację moralną w zakresie wspomagania z zewnątrz rozwoju kompetencji moralnego działania połączyć z czynieniem przez wychowanka dobra można jedynie dzięki wychowywaniu metodą zadaniową, jedynie ona bowiem pozwala wychowankowi (pod wychowawczą kontrolą) na przełożenie własnej wiedzy o dobru na dobry czyn. Wzbogacanie doświadczeń tą drogą jest dla rozwoju człowieka najistotniejsze, gdyż rozwiązywanie zadań przyczynia się zarówno do rozwoju działań, jak i do rozwoju procesów psychicznych jednocześnie (poznawczych i emocjonalnych).

Własne i cudze rozwiązywanie zadań kontekstualnych (istniejących w tle wszelkich zadań rzeczowych) niesie „materiał” do dialogu (z własnym sumieniem i otoczeniem) o własnych i cudzych wyborach moralnych. W tym okolicznościach kształtują się kompetencje moralnego działania uczestników dialogu. Sterowaniem i urabianiem (wedle strategii technologicznej) można natomiast z sukcesem wyćwiczyć zachowania, nawet zgodne z określonymi normami moralnymi, ale rezultaty tych dwu strategii edukacyjnych będą się różnić jak kompetencje od nawyku i dadzą o sobie znać zwłaszcza w sytuacjach niestereotypowych.

Zarówno w polskiej, jak i w obcojęzycznej literaturze bywa zwracana uwaga na sprzeczność pomiędzy doniosłością zadań w procesach uczenia się i nauczania a stosunkowo małym zainteresowaniem samym zadaniem ze strony teorii dydaktyki. W teorii wychowania nie jest ono wcale większe. Nawet coraz pełniejsza świadomość zniewalającego wpływu na dzieci innych środków wychowania dotąd nie przyniosła oczekiwanych zmian w tym zakresie, ciągle bowiem dostrzegana jest głównie (jeśli nie tylko) regulacyjna funkcja zadania. W praktyce edukacyjnej też nie jest lepiej. Czy tak trudno nieprofesjonalnym i profesjonalnym praktykom

narzędzia badawczego służącego ujmowaniu dydaktycznie uzasadnionych kompetencji moralnych w odniesieniu do lekcji etyki w szkołach publicznych" (http"/www.etik.uksw.edu.pl). 
rozumnie oddać rolę pierwszych skrzypiec w wychowaniu? Czy tak trudno jest nie mylić pogodzenia się z istotą twierdzenia mówiącego, że „głównym sprawcą swego rozwoju jest sam wychowanek" $z$ pełnym wychowawczego nieporozumienia sposobem interpretowania bezstresowego wychowania? I czy tak trudno jest zadać sobie trud poznania oraz zrozumienia istoty zadań kontekstualnych?

\section{Bibliografia}

Banasiak J. (1996). Reagowanie wychowawcze w wielowymiarowej pedagogice działania. Warszawa: Wydawnictwa Uniwersytetu Warszawskiego.

Benner D., von Heynitz M., Ivanov St., Nikolova R., Pohlmann C., Remus C. Nauczanie etyki i kompetencja moralna poza wdrażaniem wartości i wychowaniem do cnoty, tłum. Dariusz Stępkowski. Dostępny na: http://repozytorium. ukw.edu.pl/bitstream/handle/item/605/Nauczanie\%2oetyki\%2oi\%2okompetencja\%2omoralna\%2opoza\%2owdrazaniem\%2owartosci\%2oi\%2owychowaniem\%20do\%2ocnoty.pdf?sequence $=1$ (otwarto 25.11.2015).

Blusz K. (red.) (1992). Edukacja i wyzwolenie, Kraków: Oficyna Wydawnicza "Impuls".

Dejnarowicz W. (1977). Sytuacje i procesy wychowawcze w klasie szkolnej. Warszawa: Wydawnictwa Szkolne i Pedagogiczne.

Furmanek W. (1997). Kompetencje - próba określenia pojęcia, „Edukacja Ogólnotechniczna", nr 7.

Gnitecki J. (1996). Metodologiczne problemy pedagogiki prakseologicznej. Zielona Góra: Wydawnictwo Naukowe WSP

Horowski J. (2012). Sprawności czy kompetencje moralne?. „Paedagogia Christiana”, nr 1 (29).

Kohlberg L., Mayer R. (1993). Rozwój jako cel wychowania. W: Z. Kwieciński, L. Witkowski (red.). Spory o edukację. Dylematy i kontrowersje we współczesnych pedagogiach. Warszawa: Instytut Badań Eedukacyjnych.

Kompetencje społeczne. Dostępny na: https://pl.wikipedia.org/wiki/Kompetencje_ społeczne (otwarto: 27.11.2015).

Konarzewski K. (1982). Podstawy teorii oddziaływań wychowawczych. Warszawa: Państwowe Wydawnictwo Naukowe.

Kuchcińska M. (1988). Metoda zadaniowa w wychowaniu. Bydgoszcz: Wydawnictwo Wyższej Szkoły Pedagogicznej.

Kuchcińska M. (1996). Metoda zadaniowa w edukacji szkolnej i równoległej. Bydgoszcz: Wydawnictwo MK.

Kuchcińska M. (1997). Od edukacji dyrektywnej do emancypacyjnej. Dylematy w edukacji za pośrednictwem zadań. Bydgoszcz: Wydawnictwo Wyższej Szkoły Pedagogicznej. 
Kwaśnica R. (2004). Wprowadzenie do myślenia o nauczycielu. W: Z. Kwieciński, B. Śliwerski (red.). Pedagogika. Podręcznik akademicki, t. 2. Warszawa: Wydawnictwo Naukowe PWN.

Łukaszewski W. (1984). Szanse rozwoju osobowości. Warszawa: Wydawnictwo Książka i Wiedza.

Paszkiewicz E. (1983). Struktura teorii psychologicznych. Behavioryzm - psychoanaliza -psychologia humanistyczna. Warszawa: Wydawnictwo Naukowe PWN. Pszczołowski T. (1978). Mała encyklopedia prakseologii i teorii organizacji. WrocławWarszawa-Kraków-Gdańsk: Zakład Narodowy im. Ossolińskich.

Simon S.B., Hawley R.C., Britton D.D. (1992). Krystalizacja wartości. Ćwiczenia pisemne dla rozwoju osobowego. Toruń-Poznań: brak informacji o wydawcy.

Sobol E. (2005). Słownik języka polskiego. Warszawa: Wydawnictwo Naukowe PWN Tomaszewski T. (1971). Wstęp do psychologii. Warszawa: Wydawnictwo PWN.

Tyszkowa M. (1977). Aktywność i działalność dzieci i młodzieży. Warszawa: Wydawnictwa Szkolne i Pedagogiczne.

\title{
USE OF TASK-BASED LEARNING METHOD TO DEVELOP ETHICAL ACTION SKILLS
}

\begin{abstract}
Abstact: Teachers - one of the subjects of the education process - could rationally use the upbringing potential of their lessons if they considered the effects of the applied upbringing methods in accordance with specific models of pedagogical thinking.

In the case of the task-based method recommended in this paper, a similar result in creating ethical action skills could be obtained by analysing and exploiting the possiblities of the existing or intentionally-created contextual tasks; by solving them pupils put the knowledge about good into ways of doing good.
\end{abstract}

Keywords: means of education, object-based task, contextual task, ethical action skills, task-based learning method.

Maria Kuchcińska - doktor habilitowany nauk społecznych w zakresie pedagogiki, zatrudniona na stanowisku profesora nadzwyczajnego w Kujawsko-Pomorskiej Szkole Wyższej w Bydgoszczy. Wybrane publikacje: Od edukacji dyrektywnej do emancypacyjnej. Dylematy w edukacji za pośrednictwem zadań (1997), redakcja naukowa - Edukacja do i w starości (2008), współredakcja z Elżbietą Kościńską - Konteksty zdrowia i edukacji zdrowotnej (2010). Adres mejlowy: mariakuchcinska@wp.pl. 